\title{
Skrining fitokimia pada tanaman penyembuh luka di Lombok Timur
}

\author{
Fidrus Affandy ${ }^{1}$, Dyke Gita Wirasisya ${ }^{1 *}$, Nisa Isneni Hanifa ${ }^{1}$ \\ ${ }^{1}$ Program Studi Farmasi, Fakultas Kedokteran, Universitas Mataram, Mataram, Indonesia
}

DOI: $\underline{\text { https://doi.org/10.29303/sjp.v2i1.84 }}$

\section{Article Info}

Received : 2021-01-06

Revised : 2021-04-20

Accepted : 2021-04-20

\begin{abstract}
The ethnomedicinal study which conducted in East Lombok revealed 5 potentially plants that have wound healing properties (Jatropha multifida L., Stachytarpheta jamaicensis (L.) Vahl, Centella asiatica (L.) Urban, Euphorbia pulcherrima Willd, and Angelica keiskei). The five plants have been no further research related to the presence of compounds that have activity in wound healing. This study aims to screen the plants secondary metabolites from above plants. The sample was maserated with $96 \%$ solvent methanol. The viscous extract was determined by physical characterization including consistency and color as well as chemical characterization, namely the phytochemical screening test. The results showed that the five plants contained flavonoids, phenolics, saponins, and steroids, except for Stachytarpheta jamaicensis (L.) Vahl showed negative results for saponins and Angelica keiskei showed negative results for steroid compounds.
\end{abstract}

Keywords: phytochemical screening, total phenolic content, wound healing herbs, East Lombok

Citation: Affandy, F., Wirasisya, D. G., \& Hanifa, N. I. (2021). Skrining fitokimia pada tanaman penyembuh luka di Lombok Timur. Sasambo Journal of Pharmacy, 2(1), 1-6. doi: https:/ / doi.org/10.29303/sjp.v2i1.84

\section{Pendahuluan}

Luka merupakan suatu kejadian kerusakan sebagian dari jaringan tubuh (Sjamsuhidajat, 2010). Tubuh memiliki respon fisiologis terhadap adanya luka, yakni proses penyembuhan luka. Penyembuhan luka merupakan proses fisiologis yang panjang dan dipengaruhi oleh faktor sistemik dan lokal. Faktor sistemik berupa hormon, umur, jenis kelamin, stress, obesitas, penyakit yang diderita seperti diabetes, serta obat yang dikonsumsi. Faktor lokal dipengaruhi oleh oksigenasi serta infeksi (Guo dan DiPietro, 2010). Kasus infeksi sendiri di Provinsi Nusa Tenggara Barat masuk ke dalam 10 penyakit terbanyak dengan jumlah mencapai 29.931 kasus dan menjadi penyebab luka sukar sembuh sehingga pengendalian kejadian infeksi menjadi sangat penting (Dinkes Provinsi NTB, 2018).

Terdapat 22 tanaman di Desa Timbanuh Kecamatan Pringgasela Lombok Timur yang sering dimanfaatkan sebagai obat luka oleh masyarakat desa berdasarkan studi etnomedisin. Dua puluh dua jenis tanaman tersebut telah dilakukan preference ranking dan didapatkan 5 jenis tanaman potensial yang digunakan sebagai penyembuh luka, yakni tanaman Jatropha multifida L., Stachytarpheta jamaicensis (L.) Vahl, Centella asiatica (L.) Urban, Euphorbia pulcherrima Willd, dan Angelica keiskei (Ibrahim, 2019).

Kandungan senyawa seperti fenolik, alkaloid, saponin, flavonoid, terpenoid dan tanin yang dipercaya memiliki aktivitas antimikroba maupun antioksidan secara terpisah telah dilaporkan pada kelima tanaman tersebut, (Kumala dkk. 2016; Sopiah dkk. 2019; Suhartati dan Virgianti, 2015). Kelima jenis tanaman penyembuh luka di Desa Timbanuh ini belum diteliti lebih lanjut terkait keberadaan senyawa yang memiliki aktivitas dalam penyembuh luka. Berdasarkan masalah diatas, perlu dilakukan penelitian terkait potensi tanaman sebagai penyembuh luka berdasarkan kadar fenolik total, sehingga penelitian ini bertujuan untuk menentukan senyawa metabolit sekunder yang 
terkandung pada ekstrak metanol keenam sampel tanaman tersebut.

\section{Metode}

\section{Pengumpulan dan Preparasi Sampel}

Kelima sampel diambil sebelum jam 10.00 WITA di Desa Timbanuh, Kecamatan Pringgasela, Kabupaten Lombok Timur.

Sampel basah kelima tanaman dibuat simplisia dengan disortasi basah, dicuci hingga bersih, dirajang, dan dikeringkan. Sampel yang sudah kering diayak dengan ayakan 10 mesh. Sampel selanjutnya dimaserasi dengan pelarut metanol 96\% dengan perbandingan 1:10. Seluruh filtrat yang dihasilkan, kemudian dipekatkan dengan metode penguapan sederhana dengan suhu dibawah $60^{\circ} \mathrm{C}$ (Febrina, 2015).

\section{Karakterisasi Ekstrak}

Ekstrak kental ditetapkan karakteristik fisik meliputi konsistensi dan warna (Departemen Kesehatan RI, 2000) serta penapisan fitokimia.

1. Uji Alkaloid

Ekstrak 0,5 g dilarutkan dalam $1 \mathrm{~mL}$ asam klorida encer $2 \mathrm{~N}$ dan $9 \mathrm{~mL}$ air, panaskan diatas penangas air selama 2 menit, dinginkan dan disaring. Filtrat dibagi menjadi dua bagian, salah satu bagian ditetesi dengan pereaksi Mayer dan bagian lain ditetesi dengan pereaksi Dragendroff. Pembentukan endapan berwarna putih atau kuning pada ekstrak yang ditetesi dengan pereaksi Mayer dan pembentukan endapan merah kecokelatan sampai hitam pada ekstrak yang ditetesi dengan pereaksi Dragendroff menunjukkan adanya alkaloid (Tiwari dkk. 2011; Departemen Kesehatan RI, 1978).

2. Uji Flavonoid

Ekstrak sebanyak 0,5 g dilarutkan dalam $5 \mathrm{~mL}$ air panas, didihkan selama 5 menit, lalu disaring. Filtrat yang didapatkan lalu ditambahkan 0,1 serbuk $\mathrm{Mg}$ secukupnya, $1 \mathrm{~mL}$ asam sulfat pekat dan $2 \mathrm{~mL}$ etanol $70 \%$. Tabung dikocok kuat dan biarkan terpisah. Terbentuknya warna merah, merah ungu, kuning atau jingga pada lapisan etanol menunjukkan adanya senyawa flavonnoid (Tiwari dkk. 2011).

3. Uji Fenolik

Ekstrak sebanyak 0,5 g ditambahkan etanol $5 \mathrm{~mL}$ dan didihkan. $\mathrm{FeCl}_{3}$ ditambahkan sebanyak 3 tetes dan akan terbentuk warna merah, biru kehitaman, hijau kecoklatan, atau hitam pekat (Hapsari, 2017; Wardana dan Tukiran, 2016).

4. Uji Saponin

Pada 0,5 g ekstrak ditambahkan $5 \mathrm{~mL}$ air panas dalam tabung reaksi. Kocok campuran ekstrak dan air. Pengamatan dilakukan hingga terbentuk buih yang stabil selama 10 menit. Pada penambahan 1 tetes asam klorida $2 \mathrm{~N}$, buih tidak hilang (Departemen Kesehatan RI, 1978).

\section{Uji Triterpenoid-Steroid}

Ekstrak ditambahkan masing-masing $10 \mathrm{~mL}$ aquades dan kloroform. Kemudian dikocok kuat dan dibiarkan hingga terbentuk dua lapisan. Lapisan kloroform diambil lalu ditetesi beberapa tetes kloroform dan dibiarkan mengering. Setelah itu ditambahkan pereaksi Liebermann Burchard yang telah dipanaskan pada suhu $100^{\circ} \mathrm{C}$ selama 5-10 menit. Hasil positif terpenoid ditunjukkan dengan terbentuknya warna merah atau violet, sedangkan steroid ditunjukkan dengan terbentuknya warna hijau atau biru (Tiwari dkk. 2011).

\section{Hasil dan Pembahasan \\ Pengumpulan dan Preparasi Sampel}

Kelima sampel diambil pada pagi hari. Pembuatan simplisia dilakukan dengan cara disortasi basah, dicuci hingga bersih dengan air mengalir dan dirajang kecil-kecil (Ibrahim, 2019). Sampel selanjutnya dikeringkan untuk menghilangkan kandungan air sehingga mencegah pertumbuhan kapang dan mikroorganisme lainnya. Sampel yang sudah kering, selanjutnya dihaluskan untuk meningkatkan kontak permukaan sampel dengan pelarut saat proses ekstraksi.

Sampel diekstraksi dengan metode maserasi. Alasan pemilihan metode maserasi karena menurut Bruneton (1999) metode ini cukup sederhana, mudah dilakukan, dan jumlah pelarut yang digunakan lebih sedikit. Proses maserasi dilakukan dengan merendam sampel pada pelarut metanol $96 \%$ selama 24 jam dengan 2 kali remaserasi. Data hasil \%rendemen disajikan dalam Tabel 3. Hasil perhitungan rendemen menunjukkan pada sampel Stachytarpheta jamaicensis (L.) Vahl memiliki persen rendemen tinggi, yaitu $32,65 \%$ dibandingkan hasil penelitian Kumala dan Bekti (2016) menghasilkan persentase rendemen sebesar $15,64 \%$ pada ekstrak metanol. Perbedaan nilai persentase rendemen dapat dipengaruhi oleh derajat kehalusan simplisia. Pada penelitian Kumala dan Bekti (2016) menggunakan mesh 4 dibandingkan penelitian ini menggunakan mesh 10 yang menghasilkan perbedaan derajat kehalusan simplisia. Semakin tinggi derajat kehalusan simplisia, maka semakin besar kontak simplisia dengan pelarut (Azwanida, 2015).

\section{Karakterisasi Ekstrak}

Hasil penentuan karakterisasi fisik meliputi konsistensi dan warna ekstrak serta penapisan fitokimia untuk mengetahui adanya metabolit sekunder yang terkandung di dalam ekstrak sampel berupa flavonoid, fenolik, saponin, alkaloid, dan triterpenoidsteroid disajikan pada Tabel 1. 
Tabel 1. Hasil karakteristik fisik, rendemen ekstrak, dan penapisan fitokimia kelima sampel

\begin{tabular}{|c|c|c|c|c|c|c|c|c|c|}
\hline \multirow[b]{2}{*}{ Sampel } & \multirow[b]{2}{*}{ Konsistensi } & \multirow[b]{2}{*}{ Warna } & \multirow{2}{*}{$\begin{array}{c}\% \\
\text { rendemen }\end{array}$} & \multicolumn{6}{|c|}{ Penapisan Fitokimia } \\
\hline & & & & $\begin{array}{c}\text { Flavo } \\
\text { noid }\end{array}$ & Fenolik & Saponin & Alkaloid & $\begin{array}{c}\text { Triterpe } \\
\text { noid }\end{array}$ & Steroid \\
\hline 1 & Kental & $\begin{array}{c}\text { Hijau } \\
\text { kehitaman }\end{array}$ & $13,45 \%$ & ++++ & ++++ & +++ & - & - & + \\
\hline 2 & Kental & $\begin{array}{c}\text { Hijau } \\
\text { kehitaman }\end{array}$ & $10,76 \%$ & + & +++ & ++++ & - & - & +++ \\
\hline 4 & Kental & $\begin{array}{c}\text { Hijau } \\
\text { kehitaman }\end{array}$ & $28,19 \%$ & ++ & ++++ & +++ & - & - & + \\
\hline 5 & Kental & $\begin{array}{c}\text { Hijau } \\
\text { kehitaman }\end{array}$ & $18,96 \%$ & + & + & + & - & - & - \\
\hline 6 & Kental & $\begin{array}{c}\text { Hijau } \\
\text { kehitaman }\end{array}$ & $11,07 \%$ & +++ & + & +++ & - & - & + \\
\hline
\end{tabular}

Keterangan: (1) Euphorbia pulcherrima Willd (daun merah); (2) Euphorbia pulcherrima Willd (daun hijau); (3) Stachytarpheta jamaicensis L. Vah; (4) Centella asiatica; (5) Angelica keiskei; (6) Jatropha multifida L.

$++++\quad$ : Positif, intensitas perubahan warna sangat tinggi

$++\quad$ : Positif, intensitas perubahan warna tinggi

$+\quad$ : Positif, intensitas perubahan warna cukup tinggi

\section{Flavonoid}

Hasil analisis senyawa flavonoid dari seluruh ekstrak menunjukkan hasil positif yang ditunjukkan dengan perubahan warna setelah penambahan larutan $\mathrm{HCl}$ pekat dan serbuk $\mathrm{Mg}$. Penambahan $\mathrm{HCl}$ pekat digunakan untuk menghidrolisis flavonoid menjadi aglikon, yaitu dengan menghidrolisis O-glikosil. Glikosil akan tergantikan oleh $\mathrm{H}^{+}$dari asam karena sifatnya yang elektrofilik. Reduksi dengan $\mathrm{Mg}$ dan $\mathrm{HCI}$ pekat ini menghasilkan senyawa kompleks yang berwarna merah atau jingga pada flavonol, flavon, flavanonol dan xanton (Robinson, 1995). Adapun reaksi kimia yang terjadi dilihat pada gambar 1 .

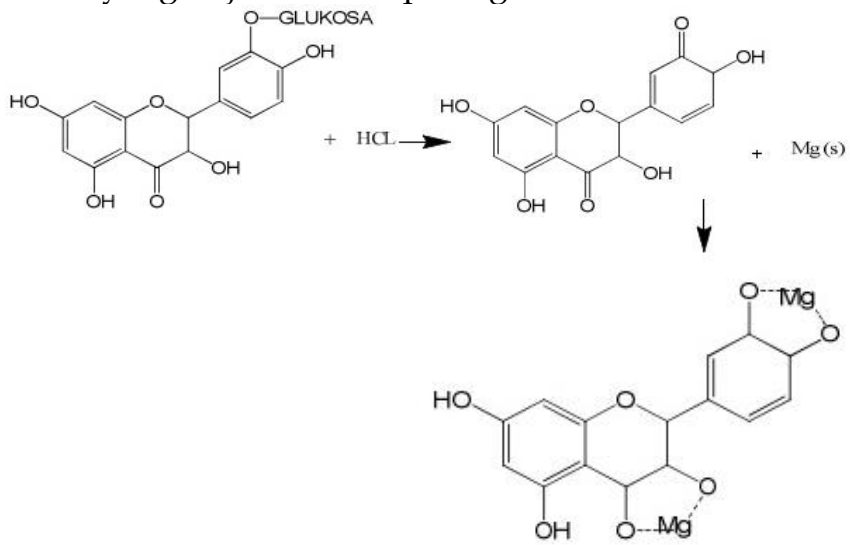

Gambar 1. Reaksi positif flavonoid (Habibi, 2017)

\section{Fenolik}

Pada uji fenolik, didapatkan hasil bahwa seluruh sampel positif mengandung senyawa fenolik. Hal ini ditandai dengan perubahan warna yang terjadi pada saat penambahan larutan $\mathrm{FeCl}_{3} 1 \%$ yaitu terbentuk $+\quad$ : Positif, intensitas perubahan warna rendah

- $\quad$ Negatif

warna hijau kehitaman karena $\mathrm{FeCl}_{3}$ bereaksi dengan gugus -OH aromatis (Haryati dkk. 2015). Kompleks berwarna yang terbentuk diduga sebagai besi (III) heksafenolat. Ion $\mathrm{Fe}^{3+}$ akan mengalami hibridisasi orbital $\mathrm{d}^{2} \mathrm{sp}^{3}$ sehingga ion $\mathrm{Fe}^{3+}\left(4 \mathrm{~s}^{0} \mathrm{~d}^{5}\right)$ memiliki 6 orbital kosong yang diisi oleh pendonor pasangan elektron, yaitu atom oksigen pada senyawa fenolik yang memiliki pasangan elektron bebas (Marliana dan Saleh, 2011). Adapun reaksi kimia yang terjadi dilihat pada gambar 2 .<smiles>Oc1ccccc1</smiles>

$$
\begin{aligned}
+\mathrm{FeCl}_{3} \longrightarrow & {\left[\left(\mathrm{C}_{6} \mathrm{H}_{5} \mathrm{O}\right)_{6} \mathrm{Fe}\right]^{3+}+3 \mathrm{HCl}+3 \mathrm{H}^{+} } \\
& \text {Kompleks berwarna hijau } \\
& \text { kehitaman }
\end{aligned}
$$

Gambar 2. Reaksi fenol dengan $\mathrm{FeCl}_{3}$ (Sagar, 1996) 3. Saponin

Pada hasil uji senyawa saponin diketahui bahwa pada sampel Jatropha multifida L., Centella asiatica (L.) Urban, Euphorbia pulcherrima Willd, dan Angelica keiskei menunjukkan hasil positif. Namun, pada sampel Stachytarpheta jamaicensis (L.) Vahl menunjukkan hasil negatif saponin. Hasil ini berbeda dengan penelitian yang dilakukan oleh Indrayani dkk. (2006) yang menunjukkan hasil positif saponin pada Stachytarpheta jamaicensis (L.) Vahl. Hal ini dapat disebabkan oleh faktor tempat tumbuh yang berbeda karena lingkungan tempat tumbuh mempengaruhi kandungan senyawa metabolit sekunder suatu tanaman. 
Hasil positif ditandai dengan terbentuknya busa setelah pengocokan. Busa yang ditimbulkan saponin dikarenakan adanya kombinasi struktur senyawa penyusunnya yaitu rantai sapogenin non-polar dan rantai samping polar yang larut dalam air (Maya dkk. 2015). Hidrolisis dengan $\mathrm{HCl}$ bertujuan untuk memutuskan gugus gula pada sampel (Marliana dkk. 2005). Adapun reaksi kimia pada uji saponin diilustrasilak pada gambar 3 .

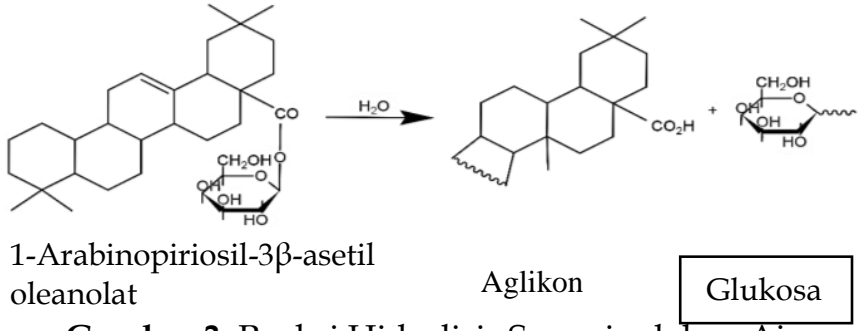

Gambar 3. Reaksi Hidrolisis Saponin dalam Air

(Habibi, 2017)

\section{Alkaloid}

Hasil uji fitokimia alkaloid menunjukkan bahwa seluruh sampel negatif alkaloid karena tidak terbentuk endapan. Namun, pada sampel Stachytarpheta jamaicensis L. menunjukkan pada pereaksi Mayer dan Dragendorff terbentuk endapan berwarna hitam. Hasil ini disimpulkan negatif alkaloid karena seharusnya pada pereaksi Mayer akan terbentuk endapan berwarna putih atau kuning serta suatu sampel dinyatakan mengandung alkaloid apabila menunjukkan hasil positif minimal menggunakan 2 pereaksi. Hasil ini tidak sesuai dengan hasil penelitian oleh Syarfati dkk. (2011); Salmiwanti dkk. (2016), Sopiah dkk. (2019) dan Sembiring dan Feri (2011) yang menyatakan bahwa tanaman Jatropha multifida L., Centella asiatica (L.) Urban, Euphorbia pulcherrima Willd, Euphorbia pulcherrima Willd dan Angelica keiskei mengandung senyawa alkaloid. Perbedaan hasil tersebut dapat dipengaruhi oleh pelarut yang digunakan. Penelitian ini digunakan pelarut metanol bersifat polar sedangkan senyawa alkaloid bersifat nonpolar, karena suatu pelarut akan lebih mudah menarik senyawa dengan kepolaran yang sama.

Pada uji alkaloid dengan pereaksi Mayer, nitrogen pada alkaloid akan bereaksi dengan ion logam $\mathrm{K}^{+}$dari kalium tetraidomerkurat (II) membentuk kompleks kalium-alkaloid yang mengendap berwarna putih (Svehla, 1990). Pada uji alkaloid dengan pereaksi Dragendorff (kalium tetraiodobismutat) menghasilkan endapan merah kecokelatan hingga hitam. Pada reaksi ini terjadi penggantian ligan dimana nitrogen yang mempunyai pasangan elektron bebas pada alkaloid membentuk ikatan kovalen koordinat dengan ion $\mathrm{K}^{+}$ dari kalium tetraiodobismutat menghasilkan kompleks kalium-alkaloid yang mengendap (endapan merah atau cokelat) (Haryati dkk. 2015).

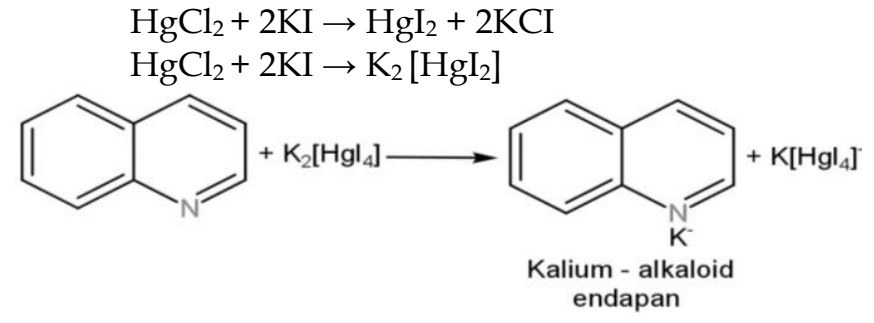

Gambar 4. Reaksi senyawa alkaloid dengan reagen Mayer (Marliana, dkk. 2005)

$$
\begin{aligned}
\mathrm{Bi}\left(\mathrm{NO}_{3}\right)_{3}+3 \mathrm{KI} & \rightarrow \mathrm{BiI}_{3}+3 \mathrm{KNO}_{3} \\
& \text { Coklat } \\
\mathrm{BiI}_{3}+\mathrm{KI} \rightarrow & \mathrm{K}\left[\mathrm{BiI}_{4}\right] \\
& \text { Kalium tetraiodobismutat }
\end{aligned}
$$

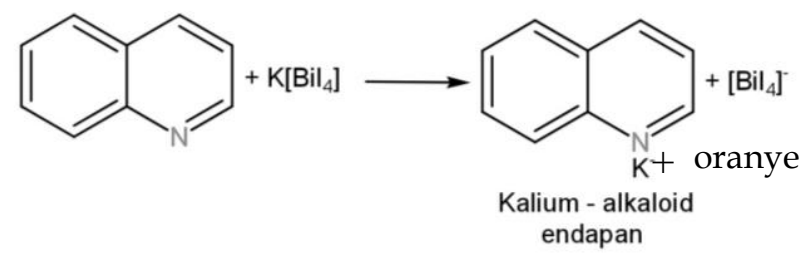

Gambar 5. Reaksi senyawa alkaloid dengan reagen Dragendorff (Haryati dkk. 2015)

5. Triterpenoid-steroid

Hasil positif ditunjukkan dengan adanya perubahan warna. Reaksi triterpenoid dengan pereaksi Liebermann-burchard menghasilkan warna merah-violet sedangkan steroid memberikan warna hijau-biru. Hal ini didasari oleh kemampuan senyawa triterpenoid dan steroid membentuk warna oleh $\mathrm{H}_{2} \mathrm{SO}_{4}$ dalam pelarut asam asetat anhidrat. Perbedaan warna yang dihasilkan oleh triterpenoid dan steroid disebabkan perbedaan gugus pada atom C-4 (Marliana dan Saleh, 2011). Adapun reaksi yang terjadi diilustrasikan pada gambar 6 dan 7.

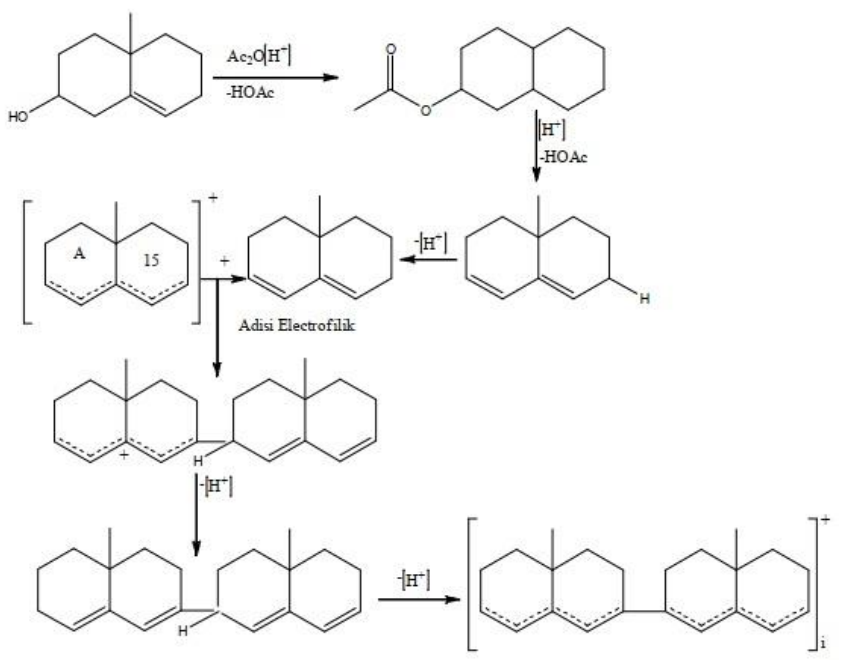

Gambar 6. Reaksi senyawa triterpenoid dengan reagen Liebermann-burchard (Nugrahani, 2016) 

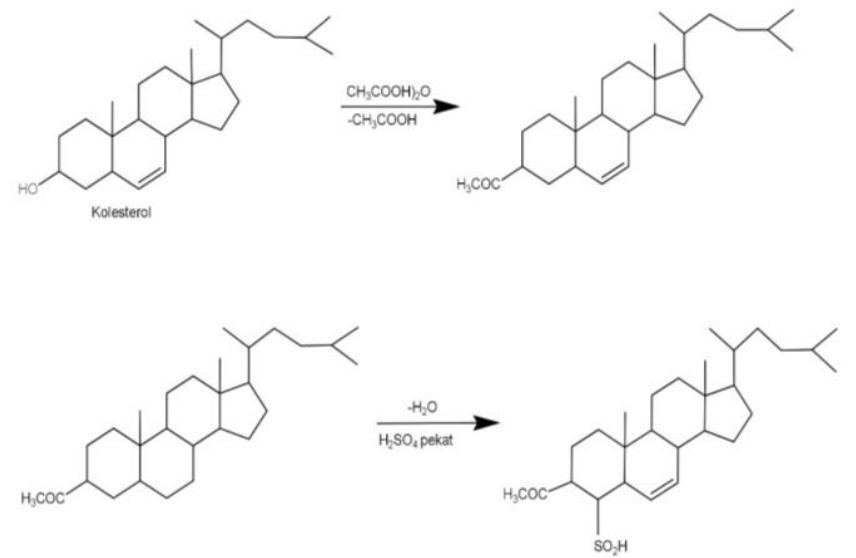

Gambar 7. Reaksi senyawa steroid dengan reagen Liebermann-burchard (Habibi, 2017)

Dari hasil analisis diketahui bahwa seluruh sampel negatif triterpenoid karena tidak terbentuknya cincin merah atau violet pada larutan uji. Hasil ini berbeda dengan penelitian oleh Sopiah dkk. (2019) dan Sembiring dan Feri (2011) yang menyatakan bahwa Euphorbia pulcherrima Willd dan Angelica keiskei menunjukkan hasil positif terpenoid. Sementara seluruh sampel menunjukkan hasil positif pada uji steroid. Hasil positif steroid diperkuat dengan penelitian yang dilakukan oleh Suhirman (2015) untuk sampel Stachytarpheta jamaicensis L. Vahl, Harliananda dkk. (2019) untuk sampel Jatropha multifida L., Sutardi (2016) untuk sampel Centella asiatica (L.) Urban, Sopiah dkk. (2019) untuk sampel Euphorbia pulcherrima Willd dan Sembiring dan Feri (2011) untuk sampel Angelica keiskei.

Berdasarkan hasil skrining fitokimia, keenam sampel berpotensi sebagai penyembuhan luka. Pada sampel Euphorbia pulcherrima Willd (daun merah) memiliki potensi lebih besar dibandingkan sampel lainnya. Hasil penelitian kualitatif sebelumnya yang dilakukan Sopiah, dkk. (2019) melaporkan bahwa Euphorbia pulcherrima Willd daun merah dan daun hijau memiliki potensi sebagai antioksidan. Selain itu, Ibrahim (2019) menyatakan bahwa Euphorbia pulcherrima Willd (daun hijau) memiliki aktivitas antibakteri pada konsentrasi ekstrak 10 dan $20 \mathrm{mg} / \mu \mathrm{L}$ dengan diameter zona hambat tertinggi sebesar 11,54 dan $15,92 \mathrm{~mm}$.

\section{Kesimpulan}

Berdasarkan penelitian yang telah dilakukan dapat disimpulkan bahwa hasil skrining kualitatif 6 sampel tanaman mengandung senyawa flavonoid, fenolik, saponin, dan steroid, kecuali pada Stachytarpheta jamaicensis (L.) Vahl menunjukkan hasil negatif senyawa saponin dan Angelica keiskei menunnjukkan hasil negatif senyawa steroid.

\section{Daftar Pustaka}

Agustina, D.R., Nurcahyanti, Lusiawati, D., dan Kris H. (2011). Aktivitas Antioksidan dan Antibakteri Ekstrak Polar dan Non Polar Biji Selasih, Jurnal Teknol dan Industri Pangan, 21(3), 1-6.

Apsari, Dwi, P., Susanti, H. (2011). Penetapan Kadar Fenolik Total Ekstrak Metanol Kelopak Bunga Rosella Merah (Hibiscus Sabdariffa Linn) dengan Variasi Tempat Tumbuh secara Spektrofotometri. Jurnal Ilmiah Kefarmasian, 2(1), 73-80.

Azwanida, N. N. (2015). A Review on the Extraction Methods Use in Medicinal Plants, Principle, Strength, and Limitation. Medical and Aromatic Plants, 4(3), 2-6.

Bruneton J. (1999). Pharmacognosy: Phytochemistry Medical Plants. $2^{\mathrm{n}}$ ed. Paris: Intercept Ltd, 297-301.

Chaithada, P., Supapan, J., Rodthuk, P., dan Chainarong, S. (2017). Total Flavonoids, Total Phenolic Content and Antioxidant Activity from Fruits, Leaves, Twigs and Flowers of Mesua Ferrea L. Walailak Journal Agricultural Technology and Biological Sciences. 15(4), 295-304.

Chun, O. K., Kim, D. O., and Lee, C. Y. (2003). Superoxide Radical Scavenging Activity of The Major Polyphenols in Fresh Plums. Journal of Agricultural and Food Chemistry, 51(27), 8067-72.

Departemen Kesehatan RI. (1978). Materia Medika Indonesia. Jilid ke-2. Departemen Kesehatan RI.

Departemen Kesehatan RI. (2000). Parameter Standar Umum Ekstrak Tumbuhan Obat. Departemen Kesehatan RI.

Dinas Kesehatan Provinsi NTB (2018). Profil Kesehatan Provinsi Nusa Tenggara Barat Tahun 2017. Dinas Kesehatan Provinsi NTB.

Febrina, L., Rolan R., dan Fairul M. (2015). Optimalisasi Ekstraksi dan Uji Metabolit Sekunder Tumbuhan Libo (Ficus Variegate Blume). Journal of Tropical Pharmacy and Chemistry, 3(2), 74-81.

Gonzalez, K. E., Colinas, M. T., Ramirez, D., Soto, R. M., dan Garcia, M. R. (2020). Antioxidant Properties in Bracts of Sun Poinsettia (Euphorbia pulcherrima) from Mexico. International Society for Horticultural Science, 1(1), 89-94.

Guo, S. dan L.A. DiPietro (2010). Factors Affecting Wound Healing. Journal of Dental Research, 89(3), 219-29.

Habibi, A. K. (2017). Skrining Fitokimia dan Aktivitas Antibakteri Ekstrak n-Heksan Korteks Batang Salam (Syzygium polyanthum). Skripsi, Semarang: Fakultas Sains dan Teknologi Universitas Islam Negeri Walisongo.

Haryati, Nur Aini, Chairul Saleh, Erwin. (2015). Uji Toksisitas dan Aktivitas Antibakteri Ekstrak Daun Merah (Syzygium mytifolium Walp) terhadap Bakteri 
Staphylococus aureus dan Escherichia coli. Jurnal Kimia Mulawarman, 13(1), 35-9.

Hapsari, W. S., Rohmayanti, Yuliastuti, F., dan Pradani, M. P. K. (2017). Skrining Fitokimia Ekstrak Etanol Herba Pegagan dan Analisa Rendemen. Proceeding $6^{\text {th }}$ University Research Colloquium, 6(1), 471-6.

Harliananda, N., Halimatussakdiah, dan Amna, U. (2019). Analisis Kualitatif Senyawa Metabolit Sekunder Daun Betadin (Jatropha multifida L.). Jurnal Kimia Sains dan Terapan, 1(1), 5-10.

Ibrahim, A. T., Sukenti, K., dan Wirasisya, D. G. (2019). Uji Potensi Antimikroba Ekstrak Metanol Daun Kastuba (Euphorbia pulcherrima Willd). Natural, 5(1), 13-8.

Kate, D. I. (2014). Penetapan Kandungan Fenolik Total dan Uji Aktivitas Antioksidan dengan Metode DPPH (1,1-Diphenyl-2-Pikrilhydrazil) Ekstrak Metanolik Umbi Bidara Upas (Merremia mammosa (Lour) Hallier f.). Skripsi, Yogyakarta: Fakultas Farmasi Universitas Sanata Dharma.

Kumala, S., Dyah, N., dan Bekti, P. (2016). Aktivitas Antibakteri dan Antioksidan Daun Pecut Kuda (Stachytarpheta jamaicensis L.) secara in Vitro. Jurnal Farmasi Indonesia, 8(2), 137-43.

Marliana, S. D., dan Saleh C. (2011). Uji Fitokimia dan Aktivitas Antibakteri Ekstrak kasar Etanol, Fraksi nHeksana, Etil asetat, dan Metanol dari Buah Labu Air (Lagenari Siceraria (Morliana) Standl. Jurnal Kimia Mulawarman, 8(2), 39-63.

Maya, S. W., Citraningtyas, G., dan Lolo, W. A. (2015). Phytochemical Screening and Antipyretic Effect of Stem Juice from Kepok Banana (Musa paradisiaca L) on White Male Rats Stain Wistar (Rattus norvegicus) Induced with DTP-Hb. Pharmacon, 4(1), 1-11.

Nugrahani, R., Andayani, Y., dan Hakim, A. (2016). Skrining Fitokimia dari Ekstrak Buah Buncis (Phaseolus vulgaris L) dalam Sediaan Serbuk. Jurnal Penelitian Pendidikan IPA, 2(1), 96-103.

Robinson, T. (1995). Kandungan Organik Tumbuhan Tinggi. $6^{\text {th }}$ ed (Terjemahan oleh Kosasih Padmawinata). K. Bandung: ITB.

Salmiwanti, Ilyas, A. dan Saleh, A. (2016). Isolasi Senyawa Metabolit Sekunder Fraksi N- Heksana dari Daun Pegagan (Centellaasiatica L.) dan Uji Antibakteri terhadap Mycobacterium tuberculosis. Al Kimia, 4(2), 52-63.

Sembiring, B. B. dan Feri M. (2011). Identifikasi Mutu Tanaman Ashitaba. Buletin Penelitian Tanaman Rempah dan Obat, 22(2), 177 - 185.

Sjamsuhidajat (2010). Buku Ajar Ilmu Bedah. Edisi ke-2. EGC. Jakarta.

Sopiah, B., Muliasari, H., dan Yuanita, E. (2019). Skrining Fitokimia dan Potensi Aktivitas Antioksidan Ekstrak Etanol Daun Hijau dan Daun
Merah Kastuba. Jurnal Ilmu Kefarmasian Indonesia, 17(1), 27.

Suhartati, R. dan Virgianti, D. P. (2015). Daya Hambat Ekstrak Etanol 70\% Daun Ashitaba (Angelica keiskei) terhadap Bakteri Staphylococcus aureus yang Diisolasi dari Luka Diabetes. Jurnal Kesehatan Bakti Tunas Husada, 14(1), 162-72.

Suhirman, S. (2015). Skrining Fitokimia pada Beberapa Jenis Pecut Kuda (Stachytarpheta jamaicensis L. Vahl). Prosiding Seminar Nasional Swasembada Pangan, 1(1), 93-7.

Sumoza, N. S., Efrizal, dan Rahayu, R. (2014). Pengaruh Gambir (Uncaira gambir R.) terhadap Penyembuhan Luka Bakar Pada Mencit Putih (Mus musculus L.) Jantan. Jurnal Biologi Universitas Andalas, 3(4), 283-2.

Sutardi (2016). Kandungan Bahan Aktif Tanaman Pegagan dan Khasiatnya untuk Meningkatkan Sistem Imun Tubuh. Jurnal Litbang Pertanian, 35(3), 121-30

Syarfati, K., Eriani, K., dan A. Damhoeri (2011). The Potential of Jarak Cina (Jatropha multifida L.) Secretion in Healing New-Wounded Mice. Jurnal Natural, 11(1), 39-44.

Tiwari, P., Kumar, B., Kaur, M., Kaur, G., dan Kaur, H. (2011). Phytochemical Screening and Extraction: A Review. Internationale Pharmaceutica Sciencia, 1(1), 98-106.

Tursiman, Puji, A. dan Risa, N. (2012). Total Fenol Fraksi Etil Asetat dari Buah Asam Kandis (Garcinia dioica Blume). Jurnal Kimia Khatulistiwa, 1(1), 45-8.

Wardana, A. P. dan Tukiran. (2016). Skrining Fitokimia dan Aktivitas Antioksidan Ekstrak Kloroform Tumbuhan Gowok (Syzygium polycephalum). Prosiding Seminar Nasional Kimia dan Pembelajarannya. Surabaya: Universitas Negeri Surabaya.

Watson, R., R. (2014). Polyphenols in Plants: Isolation, Purificaton and Extract Preparation. USA: Academic Press, 56. 